\title{
Changes on Structures of Music Presentation in Traditional Ceremony of Toba Batak Communities
}

\author{
Aprinaldi Patiaraja Simarangkir, M.Sn
}

\author{
IAKN Tarutung - Indonesia \\ april simorangkir@yahoo.com
}

\begin{abstract}
The traditional ceremony of the Toba Batak community is inseparable from the word gondang. It has a broad meaning, namely as a musical ensemble, repertoire, ceremony name, a musical composition or song title, and a set of drum musical instruments, taganing and gordang. This research is descriptive, namely research that aims to describe changes in the structure of the presentation of music in traditional Toba Batak community ceremonies, where gondang has undergone a process of enculturation in western music culture. The approach used is qualitative to answer the question 'how' the presentation structure is collaborated with modern musical instruments. The results of this study indicate that gondang and modern musical instruments have become inseparable in traditional ceremonies in the Toba Batak community specifically in North Tapanuli district. Based on the results of this study, suggestions were made for the Toba Batak community in the North Tapanuli region to prioritize the structure of gondang presentation in traditional ceremonies, so that the original culture was maintained to be continued to the younger generation.
\end{abstract}

Keywords-Structure, Music Presentation, Traditional Ceremony, Toba Batak.

\section{INTRODUCTION}

The study of musical changes was carried out by Jenifer Lindsay in her book 'Classic, Kitsch, Contemporary, a study of Javanese performances. Lindsay (1991: 10) says that the change in the use of music is not to prove or disprove a theory, but is an exploration of ideas about traditional art forms, how they are developed and the current position of the art. The depth exposes traditional and contemporary understanding by Indonesian art thinkers and artists who elaborate on developments and shifts in wayang wong art and karawitan art. According to Lindsay, the main problem in a traditional art is not the choice between preserving and changing art, or creating a gap between traditional and contemporary art, not also on preservation and change. The approach taken is that there must be an interpretation of four empirical conditions (sensual tangible goods, logic of reasoning, living norms of ethics and transcendental divinity), based on ethnic dimensions that will consider existing phenomena based on individual understanding or processes of the culture studied, and ethnic dimension elements that consider phenomena based on the overall perception of cultural studies. Thus the phenomenon of the changing structure of the gondang musical instruments in Batak land is seen holistically with the presence of a greger (phenomenon of change) in the socio-cultural sphere of the Toba Batak community. Gondang is a tradition of the Toba Batak community that is still maintained today. The word Gondang is related to many aspects. In the concept of thinking of the Toba Batak community, the words "music" give a different meaning to the words gondang. Although gondang has the meaning of musical equations, the purpose of using musical word is not the same. The word "music" is associated with modern music while the word gondang are related to traditional music. Therefore, if it is said that the traditional ceremony is accompanied by music, then the meaning is the collaboration of Western music (brass band or uning-uningan) not the accompaniment of gondang sabangunan traditional music. Based on the previous explanation, this study will describe the changes that occur in the culture of the Toba Batak people without writer distortion. The formulation of the problem used in this study is contained in two main issues including: 1). How to use modern music in the traditional ceremony of the death of the Toba Batak community? 2). What is the structure of the presentation and presentation of the repertoire of music that was used in the Toba Batak community? Changes occur in the musical aspects of accompaniment music that is contextually used in the traditional ceremonies of the death of the Toba Batak community as one of cultural expressions. So, the purposes of this study can be described as follows: 1) to find out the function of changing accompaniment music at the traditional ceremony of the death of the Toba Batak community, 2) to provide a more detailed picture of the adaptation of accompaniment music used in accompanying the 
traditional ceremony of the death of the Toba Batak community with an ethnographic study and performance art approach, 3) to explain and describe changes in the structure of presentation and repertoire of accompaniment music by examining musical aspects through analysis of the form and type of musical repertoire used in the traditional ceremonies of the death of Toba Batak community. The benefits of analysis through this research are expected as follows: 1) to provide understanding and knowledge of the genre musicals in the Toba Batak community, 2) know the changes in the structure of the presentation of music used in the traditional ceremony of the death of the Toba Batak community, 3) to give a perspective analysis and descriptive changes in the structure of presentation by music that is used in the traditional ceremonies of the death of the Toba Batak community, 4) to recognize the reconstruction of the emergence of music used in the Toba Batak culture, from the historical approach as an ethnomusicology discipline study.

\section{REVIEW OF RELATED LITERATURE}

Merriam (1964: 32-35) states that the work of analyzing a musical event is important to pay attention to various aspects including: 1). Musical sound, 2). Concepts about music, and 3). Human behavior is related to musical sounds that influence musical concepts. These three things have the same relationship in producing music sound production. Human behavior towards the concept of music, of course, is based on concepts that apply in society. These three aspects, the production of sound produced by modern music on traditional ceremonial activities, especially death, always relates repeatedly as a giving circle pattern. According to Launer (1989:25) there are some factors that push the change process include: 1 ) contact with other cultures. Before Christianity entered the Toba Batak region, taganing in the gondang sabangunan was used for local-spiritual rituals and religious ceremonies. The importance of the role of music can be seen from one of the basic spiritual philosophies of the Toba Batak community who think that, gondang is the main tool or media to achieve by building a relationship between man and the Creator (God Almighty), 2) advanced education system. Today's Toba
Batak community has experienced development in education so they are aware of loving their culture, where people always use traditional musical instruments and collaborate with modern musical instruments in every traditional ceremonial activity. The above assumptions explain the conditions seen in the music activities of the Toba Batak community in the present, have undergone a shift from the variants which are still 'original" to be a symptom of a new form of music search.

\section{RESEARCH METHOD}

This research was conducted in Tarutung in the area of North Tapanuli Regency, North Sumatra Province, which is a sub-culture of dwelling Toba Batak communities where every traditional ceremony is held routinely. In carrying out the analysis process, the presentation of music games was carried out with two analytical methods, namely: video graph; the results of footage analys is in the form of graphs presenting musical performances are guided by musical formulas performed by musicians during the performance. The first method of data analysis is data selection to select and summarize data according to the research needs of the tradition of gondang and tortor (dance). The final step is to conclude the results of the analysis in a concise and concise manner about what was found in this study. Koentjaraningrat (1991: 162) says that in a study aims to collect information about human life and its establishment in a community, and at the same time an important part when making observations. The interview is a question and answer process between the researcher and the informant about the problem being examined. In addition, interviews are also very supportive in completing the data obtained from observations, as well as from existing library data.

\section{RESEARCH RESULT}

Structure of Music Presentation in Traditional Ceremony of Toba Batak Community

The structure of the presentation of gondang in the traditional ceremonies of death with a marriage ceremony is almost the same, which distinguishes only the tempo and rhythm of the song more closely at the traditional wedding ceremony and slower at the death ceremony. The result of analysis showed as follows:

Presentation Structure of Gondang Sabangunan at Indigenous ceremonies

(events, activities and participants, the objectives of presenting ritual music)

\begin{tabular}{clll}
\hline Structure & \multicolumn{1}{c}{ Events } & \multicolumn{1}{c}{ Activities and Participants } & \multicolumn{1}{c}{ Objectives } \\
\hline A1 & Manggalang Pargonsi & host (S) & - respects \\
& & entertain musicians (M) & - tells musicians the purpose of \\
& & ceremony
\end{tabular}


- musicians present betel nut to badia ni guru

A Panjujuran gondang

A3 Mambuat Tua ni gondang

B Gondang Dalihan Na Tolu

C Closing gondang musician (M) present sipitu gondang (without dance)

\author{
- host (S) conveys customprotocol, asking \\ musicians (M) to play gondang (triad \\ structure) \\ - Musicians (M) play gondang \\ - host (S) manortor (dancing)
}

- host (S) and relatives (Kr) deliver a traditional speech, asking musicians (M) to play gondang (triad structure) - host (S) and relatives (Kr) manortor (dancing)

- host (S) and relatives $(\mathrm{Kr})$ give and receive blessing through symbolic tortor (dancing).

- host (S) and relatives (Kr) giving and receiving ceremonial gifts

Musicians (M) sing sipitu gondang
- delivering the purpose of ceremony

respect to badia ni guru (BNG); requesting permission to play gondang sabangunan; request protection from badia ni guru (BNG)

request blessings from serving the first gondang sabangunan and tortor

Expressing kinship solidarity and strengthening other kinship relations

Ending the presentation of gondang sabangunan

The triad structure of the presentation of Gondang Sabangunan in Gondang Dalihan Na Tolu

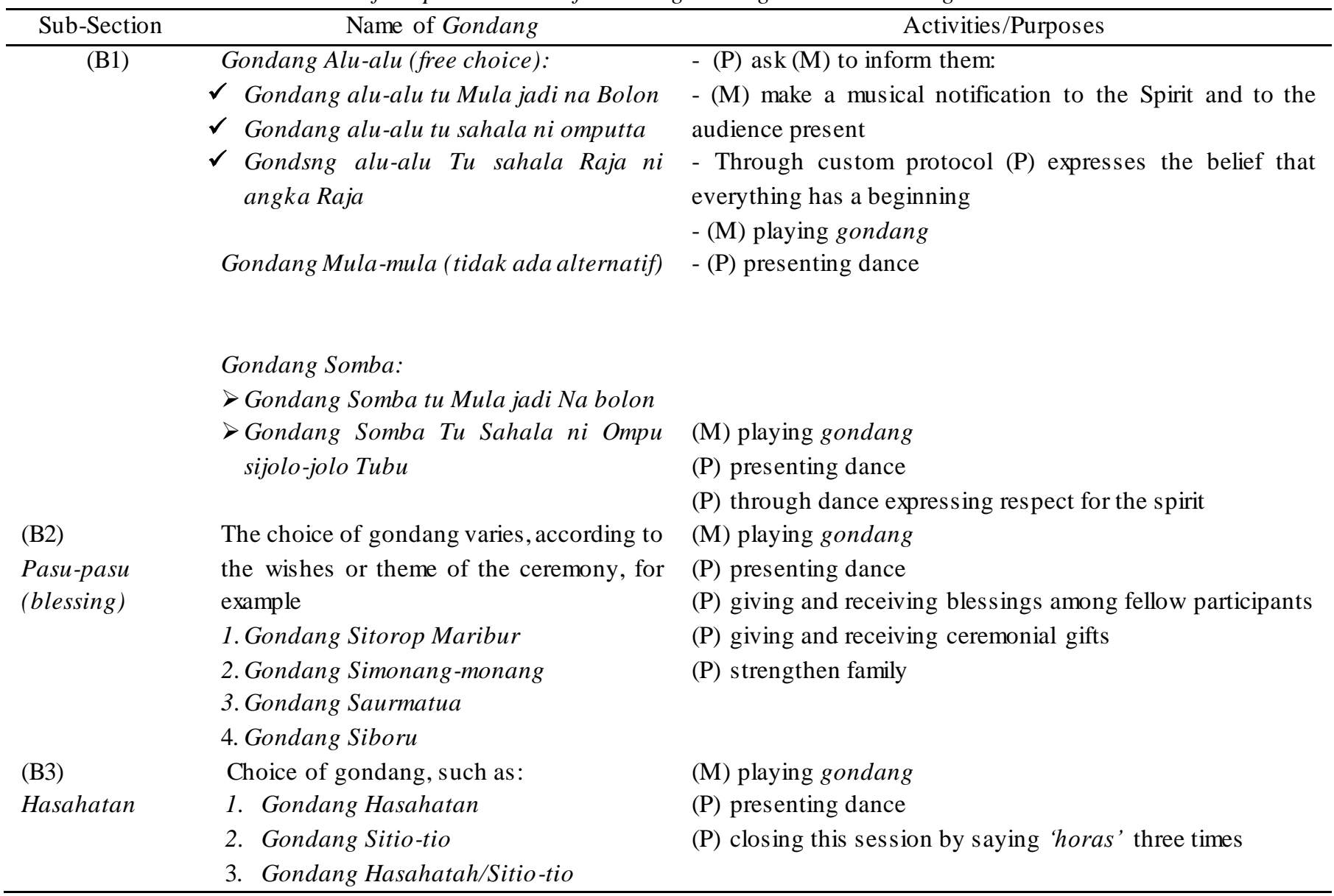




\section{CONCLUSION}

Based on the results of this study, it can be concluded that the form of music in the gondang sabangunan ensembles of traditional musicians is no longer the same as the arrangement of instruments in the form or formation of instruments in the past. This can be seen from the taganing instrument collaborated with snare drum and cymbals, and modern instruments. With the change of musical accompaniment so that it affects the form of music produced. The sense of love of the Toba Batak people in the North Tapanuli region towards gondang sabangunan has begun to diminish, because it is influenced by modern musical instruments. So the presentation of gondang sabangunan music in traditional ceremonies is less appreciated by the community. Then, writer submits the following suggestions. Firstly, for the Toba Batak community in the North Tapanuli region, continue to preserve traditional musical instruments, because these cultural products become assets that can be passed on to the next generation. Secondly, it is better if gondang built the initial version, can be collaborated with modern musical instruments to be presented in the traditional ceremonies of the Toba Batak community without eroding the aesthetics in the typical traditional music, so as to create new nuances that will add harmony to the music so that there is a sense of love traditional as well as with modern music culture.

\section{REFERENCES}

[1] Behague, G. H., ed. (1984), "Performance Practice: Etnomusikologycal Perspectives", Westport, CT.:Greenwood Press.

[2] Bodholt, P. (1975). Darah Batak dan Jiwa Protestan. Jakarta: Gunung Mulia.

[3] Geertz, C. (1992). Kebudayaan dan Agama. Yogyakarta: Kanisius.

[4] Gultom, N. R. (1990). Suatu studi Deskriptif dan musikologis Upacara Gondang saem di Desa Paradun. Skripsi Fakultas Sastra Universitas Sumatera Utara. Medan

[5] Hutajulu, R dan Irwansyah, H. (2005). Gondang Batak Toba. Bandung: PAST UPI.

[6] Koentjaraningrat. (1981). Metode Penelitian Masyarakat. Jakarta: Balai Pustaka.

[7] Launer, R. H. (1989). Perspektif Tentang Perubahan sosial. Jakarta: Bina Kasara.

[8] Lumban Tobing, P.H.L. (1995). The Structure of The Toba-Batak Belief in The High God. Amsterdam: Jacob Van Campen.

[9] Manalu, I. (1985). Mengenal Batak. Medan: CV. Kiara

[10] Merriam. P. A. (1964). The Anthropology of Music. Chicago: Northwester University Press.
[11] Moleong, J. L. (2013). Metodologi Penelitian Kualitatfi, Edisi Revisi. Bandung: PT. Remaja Rosdakarya.

[12] Pasaribu, Ben (eds). (2004). Pluralitas Musik Etnik. Medan. Pusat Dokumentasi dan Pengkajian Kebudayaan Batak. Universitas HKBP Nommensen.

[13] Purba, Mauly, 2007. Musik tradisional Masyarakat Sumatera Utara: Harapan Peluang dan Tantangan, Pidato Pengukuhan Jabatan Guru Besar Tetap dalam Bidang Ilmu Etnomusikologi Pada Fakultas Sastra. Universitas Sumatera Utara. Medan.

[14] Purba, M. (1998). Musical and Functional Change in The Gondang Sabangunan Traditional Of The Protestant Toba Batak 1860s-1990s, With Particular Reference To The 1980s-1990”. Dissertation. Australia: Monash University. 